\title{
Influence of fast pyrolysis conditions on yield and structural transformation of biomass chars
}

\author{
Anna Trubetskaya a,*, Peter Arendt Jensen ${ }^{a}$, Anker Degn Jensen ${ }^{a}$, Markus Steibel ${ }^{b}$, \\ Hartmut Spliethoff ${ }^{\mathrm{b}}$, Peter Glarborg ${ }^{\mathrm{a}, *}$ \\ a Department of Chemical and Biochemical Engineering, Denmark Technical University, Søltofts Plads Bygning 229, Kgs. Lyngby 2800, Denmark \\ b Department of Mechanical Engineering, Institute for Energy Systems, Technical University of Munich, Boltzmannstrasse 15, 85747, Garching, Germany
}

\section{A R T I C L E I N F O}

\section{Article history:}

Received 14 July 2015

Received in revised form 29 August 2015

Accepted 30 August 2015

Available online 19 September 2015

\section{Keywords:}

Fast pyrolysis

Wire mesh reactor

Heating rate

Char plasticization

Alkali

\begin{abstract}
A B S T R A C T
Fast pyrolysis of biomass (wood, straw, rice husk) and its major components (cellulose, hemicellulose, lignin) was conducted in a wire mesh reactor. The aim of this study was to understand the influence of temperature $\left(350-1400{ }^{\circ} \mathrm{C}\right)$, heating rate $\left(10-3000{ }^{\circ} \mathrm{C} / \mathrm{s}\right)$, particle size $(0.05-2 \mathrm{~mm})$ and holding time $(1-4 \mathrm{~s})$ on the char morphology and char yield. Scanning electron microscopy (SEM) and elemental analysis were conducted to determine the effect of operating conditions on char softening and melting during pyrolysis. The char yield decreased with heating rate for rates $\leq 600{ }^{\circ} \mathrm{C} / \mathrm{s}$; above this value a similar biomass char yield was obtained. The potassium content affected the char yield stronger than other minerals, while the distribution of the three major biomass constituents (cellulose, hemicellulose, lignin) affected the char yield only to a minor degree. Moreover, it was found that the heat treatment temperature had a larger influence on the char yield than the heating rate. Scanning electron microscopy indicated different types of biomass char plasticization influenced by the applied temperatures, heating rates, particle sizes and holding times, except for the rice husk char that formed chars with a structure similar to the parental fuel at all conditions. The less severe morphological changes of rice husk char were attributed to a high silica content.
\end{abstract}

(c) 2015 Elsevier B.V. All rights reserved.

\section{Introduction}

Biomass and waste combustion are significant sources of renewable electricity supply in Denmark. Currently, Danish pulverized fuel fired power plants are in a transition to $100 \%$ biomass firing to reduce the emission of greenhouse gases. The utilization of biomass leads to a range of major technical challenges for the boiler and flue gas cleaning units, due to different chemical and physical properties compared to coal, reducing reliability and efficiency of power plants and creating limits for the amount of biomass that can be supplied to the power plant.

One of the major challenges is related to the quality of agricultural residues, with a higher ash content of problematic elements that may cause slagging and fouling. Another problem is the chemical structure and morphology of woody and herbaceous biomass, which may hamper grinding to small particle size fractions $(<0.5 \mathrm{~mm})$. Fine biomass milling is energy-consuming, and fibrous particles with low bulk densities may cause feeding problems. Large biomass particles may create challenges with flame stability, burnout and ignition $[1,2]$. The challenge of achieving high fuel conversion at short residence times depends on biomass

\footnotetext{
* Corresponding authors.

E-mail addresses: atru@kt.dtu.dk (A. Trubetskaya), pgl@kt.dtu.dk (P. Glarborg).
}

origin, morphological changes of fuel particle of different sizes, char yield, fuel reactivity, heating rate, local oxygen concentration and temperature in the boiler [3,4].

Fast pyrolysis at high temperatures and heating rates is the initial step of the pulverized biomass combustion. Similar to coal combustion, the fuel burn out is known to be influenced by the yield and reactivity of chars, produced during pyrolysis [3]. The rapid heating of small biomass particles and the short residence time at high temperatures minimize the char yield and increase char reactivity [5]. The majority of previous investigations [3,6-19] referred to low-ash containing feedstocks (softwood, hardwood). The effects of heating rate and temperature on the morphological transformations at both slow $\left(<10{ }^{\circ} \mathrm{C} / \mathrm{s}\right)$ and intermediate and fast pyrolysis environments $\left(>100{ }^{\circ} \mathrm{C} / \mathrm{s}\right)$ of the same feedstock were rarely studied. Most studies report influences of operational conditions at high heating rate on the chemical structure and morphology of chars. The effect of char plastic deformation with the occurrence of melting was emphasized at high heating rates. The char fluidity of coal and lignin during pyrolysis was described by the FG-DVC model (Functional Group - Depolymerization, Vaporization and Cross-linking model) of Solomon et al. [20,21]. They pointed out that small differences in the cross-linking rate affect drastically the fluidity of the resulting metaplast. Cetin et al. [3] recalled the occurrence of biomass plastic deformation as an effect of a high heating rate and rated this phenomena in terms of char ability to melt (softwood $>$ hardwood $>$ bagasse). 
In the current fast pyrolysis study, the effects of temperature, heating rate, particle size, residence time, inorganic matter and major organic components of biomass on the char yield and morphology are investigated at high temperature conditions in a wire mesh reactor (WMR). The structural char transformations, particularly char fluidity, are characterized by scanning-electron microscope (SEM).

\section{Materials and methods}

\subsection{Raw samples}

Pinewood, beechwood, Danish wheat straw, leached Danish wheat straw, alfalfa straw and rice husk were used in this work to represent softwood, hardwood and agricultural residues. The low-ash containing wood (pinewood, beechwood) of syringyl (S) or guaiacyl-syringyl (GS) lignin types and grass (wheat straw, alfalfa straw, rice husk) of hydroxy phenol-guaiacyl-syringyl (HGS) lignin type, which are rich in $\mathrm{K}, \mathrm{Ca}$ and Si elements, were selected to investigate the effect of differences in ash composition and organic matter (cellulose, hemicellulose, lignin) on the char yield and structural transformations. The fuels were milled on a Retsch rotor mill RZ200 and sieved to particle size fractions of $0.05-0.2 \mathrm{~mm}, 0.25-0.355 \mathrm{~mm}, 0.355-0.425 \mathrm{~mm}, 0.425-0.6 \mathrm{~mm}$, $0.425-0.6 \mathrm{~mm}, 0.6-0.85 \mathrm{~mm}$ and $0.85-1 \mathrm{~mm}$. Two types of Organosolv lignin made from softwood and wheat straw (purity $>94 \%$ ) were provided by BOC Sciences. Cellulose Avicel ${ }^{\mathbb{R}}$ (purity $>99.9 \%$ ) and xylan from beechwood (purity $>90 \%$ ) were supplied by Sigma-Aldrich. The purity of xylan was additionally improved from $90 \%$ to $96.6 \%$ by a three step procedure involving a strong alkali treatment, bleaching and acetylation. The proximate and ultimate analyses of the fuels are shown in Table 1.

The wheat straw was leached in deionized water (room temperature) by continuous stirring for $12 \mathrm{~h}$, followed by drying at $30{ }^{\circ} \mathrm{C}$ in an oven desiccator without any ventilation. The mineral content after biomass leaching was determined by ash analysis. Due to the wheat straw leaching, the metal content was reduced to $\approx 60 \%$ of the original value and the $\mathrm{Cl}, \mathrm{S}, \mathrm{K}, \mathrm{Na}$ and $\mathrm{P}$ contents were strongly reduced.

\subsection{Biomass compositional analysis}

The compositional analysis of biomasses (cellulose, hemicellulose, acid-soluble lignin, acid-insoluble lignin, protein and extractives) was conducted according to NREL technical reports [22-27] and Thammasouk et al. [28], and shown in Table 2.

Two different extractions were performed on the fuels using acetone or ethanol-water as a solvent (room temperature). The detailed procedure of extraction with acetone and ethanol-water is described in the supplemental material.

\subsection{Experimental procedures}

\subsubsection{Wire mesh reactor}

The effects of the particle size and holding time on the biomass char yield were studied on the wire mesh reactor at TU Munich [29]. A reconstructed version of the reactor was used to study the influence of the temperature and the heating rate on the char yield and the structural transformation of biomasses as shown in Fig. 1. The reconstructed wire mesh reactor could be operated at temperatures up to $1700{ }^{\circ} \mathrm{C}$, heating rates up to $5000{ }^{\circ} \mathrm{C} / \mathrm{s}$, and pressures up to 50 bar, whereas the original WMR could be operated at temperatures up to $1400{ }^{\circ} \mathrm{C}$, heating rates up to $3000{ }^{\circ} \mathrm{C} / \mathrm{s}$. The reconstructed wire mesh reactor encloses a tar collection filter at the top of the casing. The optical ports of the original wire mesh reactor were replaced with a cylindrical chamber to ensure a better sealing.

The cylindrical reactor chamber was enclosed into a stainless steel casing by six bolts. The welded stainless steel mesh (316 L, TWP Inc., mesh width of $0.042 \mathrm{~mm}$ ) was bended in two equal-length parts, forming a small bag with a surface area of $20 \mathrm{~mm} \times 20 \mathrm{~mm}$. The bended mesh served as a sample holder and resistance heater. The sample temperature was monitored in dependency on the experimental heat treatment temperature by either a thermocouple type $\mathrm{K}$ (max. $1000{ }^{\circ} \mathrm{C}$ ), type $\mathrm{S}\left(\max .1450{ }^{\circ} \mathrm{C}\right.$ ) or type $\mathrm{B}\left(\max .1700{ }^{\circ} \mathrm{C}\right.$ ) with a diameter of $0.051 \mathrm{~mm}$. The two wires of a thermocouple (type $\mathrm{K} / \mathrm{S} / \mathrm{B}$ ) were directly welded into the middle of the upper mesh side to determine the mesh temperature based on the Seebeck effect. The control system

Table 1

Proximate and ultimate analysis of fuels (on \%dry basis) and ash analysis (on $\mathrm{mg} / \mathrm{kg}$ dry basis).

\begin{tabular}{|c|c|c|c|c|c|c|c|c|}
\hline Fuel & Pinewood & Beechwood & Wheat straw & Leached wheat straw & Alfalfa straw & Rice husk & Lignin wheat straw & Lignin softwood \\
\hline \multicolumn{9}{|c|}{ Proximate and ultimate analysis $(\% \mathrm{db})$} \\
\hline Moisture ${ }^{a}$ & 5.1 & 4.5 & 5.5 & 4.3 & 5.2 & 4.5 & 4.4 & 6.1 \\
\hline Ash $\left(550{ }^{\circ} \mathrm{C}\right)$ & 0.3 & 1.4 & 4.1 & 2 & 7.4 & 21.7 & 3.6 & 1.3 \\
\hline Volatiles & 86.6 & 79.4 & 77.5 & 84.2 & 75.9 & 64.3 & 66.3 & 67.3 \\
\hline $\mathrm{HHV}^{\mathrm{b}}$ & 21.6 & 20.2 & 18.8 & 18.7 & 19.7 & 15.5 & 26.7 & 26.4 \\
\hline $\mathrm{LHV}^{\mathrm{b}}$ & 20.2 & 19 & 17.5 & 17.4 & 16.9 & 14.5 & 25.5 & 25.2 \\
\hline C & 50.5 & 46.7 & 42.4 & 45.7 & 42.5 & 35.5 & 61.8 & 64.6 \\
\hline $\mathrm{H}$ & 6.8 & 6.3 & 6.3 & 6.6 & 6.1 & 5.5 & 3.8 & 5.3 \\
\hline $\mathrm{N}$ & 0.1 & 0.3 & 1 & 0.3 & 3.3 & 0.1 & 1.4 & 0.8 \\
\hline \multicolumn{9}{|c|}{ Ash compositional analysis ( $\mathrm{mg} / \mathrm{kg} \mathrm{db})$} \\
\hline $\mathrm{S}$ & $<0.01$ & 0.02 & 0.1 & 0.02 & 0.03 & 0.03 & 0.8 & 0.1 \\
\hline $\mathrm{Cl}$ & 0.01 & 0.02 & 0.1 & 0.01 & 0.5 & 0.05 & 0.03 & 0.5 \\
\hline $\mathrm{Al}$ & 10 & 10 & 150 & 100 & 600 & 70 & 300 & 100 \\
\hline $\mathrm{Ca}$ & 600 & 2000 & 2500 & 1300 & 12,900 & 750 & 200 & 250 \\
\hline $\mathrm{Fe}$ & 20 & 10 & 200 & 350 & - & 80 & 1400 & 600 \\
\hline K & 200 & 3600 & 11,000 & 1300 & 28,000 & 2500 & 270 & 80 \\
\hline $\mathrm{Mg}$ & 100 & 600 & 750 & 350 & 1400 & 400 & 40 & $<30$ \\
\hline $\mathrm{Na}$ & 30 & 100 & 150 & 50 & 1000 & 70 & 6800 & 4100 \\
\hline $\mathrm{P}$ & 6 & 150 & 550 & 80 & 1900 & 600 & 30 & 30 \\
\hline $\mathrm{Si}$ & 50 & 200 & 8500 & 6200 & 2000 & 98,500 & 4000 & 900 \\
\hline $\mathrm{Ti}$ & 2 & $<8$ & 10 & 10 & 30 & 5 & 100 & 50 \\
\hline
\end{tabular}

\footnotetext{
a wt.\% (ar).
}

b In $\mathrm{MJ} / \mathrm{kg}$. 
Table 2

Biomass feedstock composition, calculated in percentage based on dry weight $(\% w / w)$.

\begin{tabular}{|c|c|c|c|c|c|c|c|}
\hline \multirow[t]{2}{*}{ Biomass } & \multirow[t]{2}{*}{ Cellulose } & \multirow[t]{2}{*}{ Hemicellulose } & \multicolumn{2}{|l|}{ Lignin } & \multirow[t]{2}{*}{ Total lignin } & \multirow[t]{2}{*}{ Extractives } & \multirow[t]{2}{*}{ Protein } \\
\hline & & & Acid insoluble & Acid soluble & & & \\
\hline Pinewood & 38.3 & 17.8 & 29.6 & 1.8 & 31.4 & $8.8^{\mathrm{a}}$ & 0.6 \\
\hline Beechwood & 35 & 19.2 & 32 & 1.5 & 33.5 & $7.5^{\mathrm{a}}$ & 1.9 \\
\hline Wheat straw & 35.9 & 18 & 19.2 & 6.5 & 25.7 & $10.1^{\mathrm{b}}$ & 6.3 \\
\hline Alfalfa straw & 18.8 & 12 & 14.7 & 6.8 & 21.5 & $39.6^{\mathrm{b}}$ & 5.1 \\
\hline Rice husk & 36.7 & 17.7 & 21.6 & 1.2 & 22.8 & $1^{\mathrm{b}}$ & - \\
\hline
\end{tabular}

a Acetone extraction.

b Ethanol-water extraction.

was based on the LabView software (Version 8.6), and consisted of a PID controller that adjusted the power output to the required temperature.

The temperature distribution on the wire mesh was assumed to be uniform. However, on the mesh side near the electrodes, the temperature could be lower than in the middle as reported by Hoekstra et al. [30]. In order to ensure high reproducibility of char yield data, the

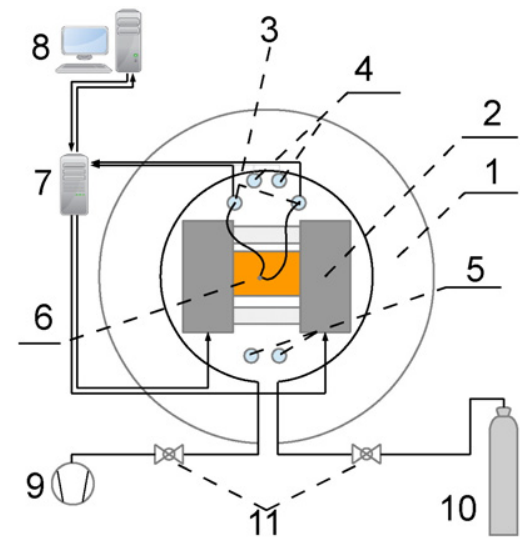

1.1: Schematic top view of the wire mesh reactor at TU Munich

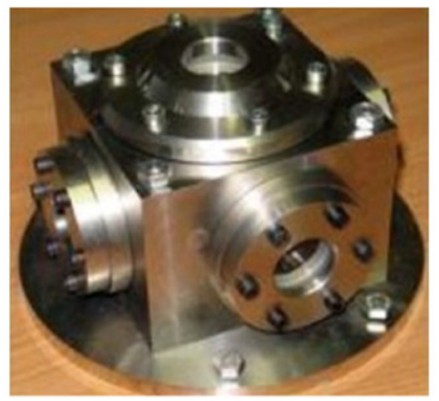

1.2: Photo of WMR before reconstruction

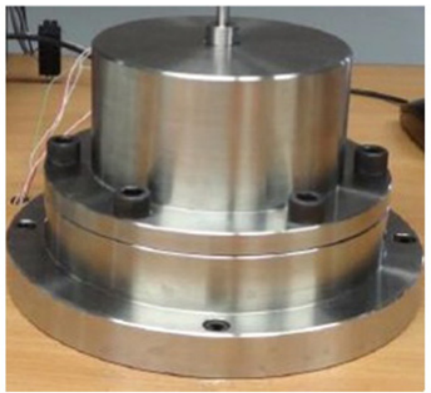

1.3: Photo of WMR after reconstruction

Fig. 1. Wire mesh reactor at TU Munich 1. Reactor steel casing; 2 . Electrodes and holder of the wire mesh with a sample; 3 . Thermocouples B-type; 4. Thermocouples S-type; 5. Thermocouples K-type; 6. Wire mesh with a sample; 7. Intensifier; 8. PC with LabVIEW software; 9. Vacuum pump; 10. Gas bottle; 11 . Valves. sample was therefore placed centrally. The sample mass of $5 \pm 1 \mathrm{mg}$ for each experiment was selected based on the previous studies of Nola et al. [14] to achieve one monolayer of particles within a mesh bag. The fuel sample was distributed homogeneously in the mesh bag by using compressed air to remove particles of size $<0.042 \mathrm{~mm}$. The wire mesh with the fuel sample was clamped between two electrodes. A two-stage rotary vane pump was used to remove air from the reactor before the experiment. The mesh was continuously swept by nitrogen at a defined flow rate to remove volatiles from the fuel during experiments.

Due to the inaccuracy of mass balance closures and char recovery using entrained-flow systems, the wire mesh reactor appears as a more reliable instrument for measuring char yields as the effect of secondary reactions in the sample and over the grid can be minimized. In this study, the effects of temperature, heating rate, particle size, holding time on the char yield and morphology were investigated with the wire mesh reactor.

\subsubsection{Tubular furnace}

A tubular reactor (TR), placed in a furnace (Entech, ETF3050/15S) was used for fixed-bed pyrolysis with a heating rate of $<10{ }^{\circ} \mathrm{C} / \mathrm{min}$ and a temperature up to $1400{ }^{\circ} \mathrm{C}$. The furnace consisted of a stainless steel tube with an alumina tube fitted with electrical heating elements and gas supply. $5 \mathrm{mg}$ of the virgin sample was loaded into the alumina boat placed in the furnace middle. The tubular reactor was purged with $\mathrm{N}_{2}$. Once the preset temperature was reached, the sample was kept for about $10 \mathrm{~min}$ or $4 \mathrm{~h}$ in the furnace to ensure complete conversion. In the current investigation, the chars, prepared in the tubular reactor under slow heating, were applied to study morphological transformations.

\subsubsection{Solid residue characterization}

The solid char was collected from each experiment in the wire mesh reactor and the tubular furnace. Elemental analysis, Scanning-Electron Microscopy (SEM) with Energy Dispersive X-ray Spectroscopy (EDS) function were used to the chars characterize morphology. SEM/EDS analysis was performed on a microscope (FEI Company, Inspect) with a tungsten filament under high vacuum in order to understand char structural and chemical properties. Prior to the analysis, char samples were coated with a thin layer of carbon ( $40 \mathrm{~s}, 5 \mathrm{~mA}$ ) using a Cressington 208 Carbon Coater to avoid sample charging. SEM/EDS analysis in a backscattered electron mode was carried out as an average composition of 20 points on different char particles.

\subsubsection{Measurement uncertainty}

The error bars represent standard deviation from the mean of the series of experiments at each condition in the WMR. The char yield data obtained for each condition was plotted as a representative average of at least five experiments. The experiments conducted at $600{ }^{\circ} \mathrm{C}$ were repeated ten times due to a high uncertainty in the char yield measurement. The absolute extended uncertainty of the product yield was determined by Gaussian error propagation procedure [31], based on the equations shown in the supplemental material. The average standard measurement error in the present study was $\pm 5 \mathrm{wt} . \%$, within a $90 \%$ 
confidence interval for the WMR experiments. The inaccuracy in determining the char yield was mainly caused by weighting errors. The char yields obtained from both wire mesh reactors were practically the same $(<1.5 \%)$ as it was shown in the supplemental material.

\section{Results and discussion}

\subsection{Char yield}

The influence of temperature, heating rate, particle size, holding time and biomass origin on the char yields were studied in the wire mesh reactor at TU Munich. Products resulting from the biomass pyrolysis included gases, tar, reaction water and solid char. The char yield $\left(\mathrm{Y}_{s}\right)$ was defined as a non-devolatized solid fraction of the reacted biomass, remaining on the mesh after an experiment.

$Y_{s}[w t \%]=\frac{m_{m e s h+c h a r}-m_{m e s h}}{m_{m e s h+\text { biomass }}-m_{m e s h}} \cdot 100$

The characterization work was carried out on the combined char from several experiments. The volatile yield was determined by the difference between the total weight loss and the non-devolatized solid fraction. The elemental analysis of the biomasses and chars is shown in supplemental material.

\subsubsection{Effect of temperature and inorganic matter}

Pyrolysis experiments in a $\mathrm{N}_{2}$ flow were carried out in the wire mesh reactor. The volatile yield for a range of biomasses, sieved to 0.05- $0.2 \mathrm{~mm}$, with a heating rate of $1000{ }^{\circ} \mathrm{C} / \mathrm{s}$ and a holding time of $1 \mathrm{~s}$ was measured as a function of temperature. The holding time of $1 \mathrm{~s}$ was considered to be sufficient for the complete pyrolysis of particles $<0.2 \mathrm{~mm}$, as reported by Werkelin et al. [32].

The char yields of pinewood, beechwood, wheat straw, alfalfa straw, leached wheat straw and rice husk are plotted versus the heat treatment temperature, on a dry and ash free basis in Fig. 2. Pinewood pyrolysis is characterized by a lower char yield in comparison to the other fuels due to the low ash content. The higher char yields of wheat straw and alfalfa straw relative to the char yields of wood, leached wheat straw and rice husk may be associated with the catalytic effect of alkali metals that affect polymerization/cross-linking.

The reduced char yield for the leached wheat straw char in comparison to the untreated wheat straw is consistent with the hypothesis that $K$ catalyzes the repolymerization and cross-linking reactions to char, as observed also by Jensen et al. [33] and Nik-Azar et al. [34]. The high level of potassium in the wheat straw and alfalfa straw may catalyze the conversion of bridges into char link, promoting faster devolatilization rates and suppressing tar formation [35], leading to the higher char yields.

The lower char yield from pinewood pyrolysis in comparison to the beechwood may be related to the lower presence of $\mathrm{K}$ and Ca cations in the original pinewood. Interestingly, the char yield of pinewood, leached wheat straw and rice husk at temperatures above $1000{ }^{\circ} \mathrm{C}$ is equally low (ca. $4 \%$ daf). This indicates that any differences in major plant components (cellulose, hemicellulose and lignin) between straw and wood give rise to only small differences in the char yield, and in any case much smaller influence than potassium on the char formation.

The largest biomass compositional difference in this study is related to the large content of extractives and protein in the alfalfa straw, constituting up to $50 \%$ of the total fuel carbohydrates. The alfalfa straw has a char yield which is similar to wheat straw at $\mathrm{T}>600{ }^{\circ} \mathrm{C}$, again indicating that differences in the composition of organic matter are less important than the influence of potassium. Interestingly, the higher alkali amount in the original alfalfa straw ( $2.8 \%$ of $\mathrm{K}$ and $1.3 \%$ of $\mathrm{Ca}$ ) than in the wheat straw ( $1.1 \%$ of $\mathrm{K}$ and $0.24 \%$ of $\mathrm{Ca}$ ) seems to have no influence on the char yield. The effect of sodium on the decomposition cannot be clearly concluded based on its low presence in wood and herbaceous biomass, used in this study. The high Si content in the rice

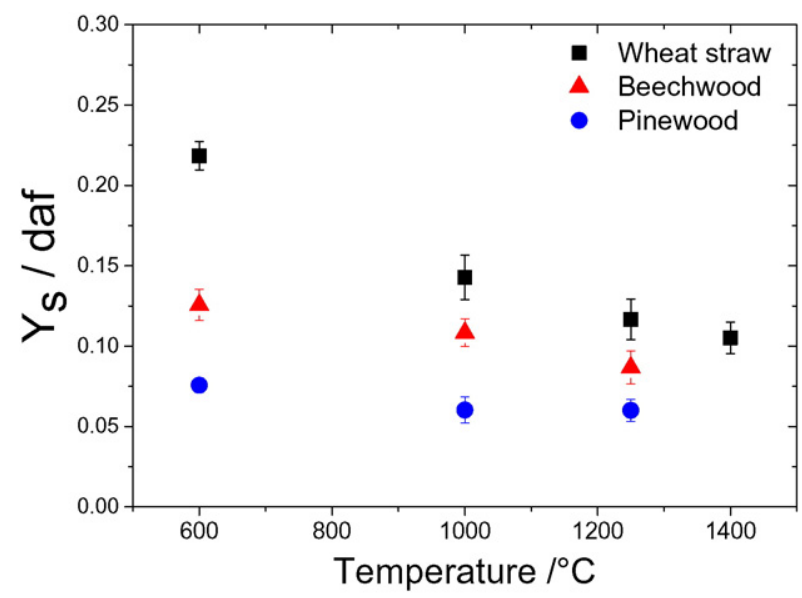

2.1: Wheat straw, beechwood, pinewood

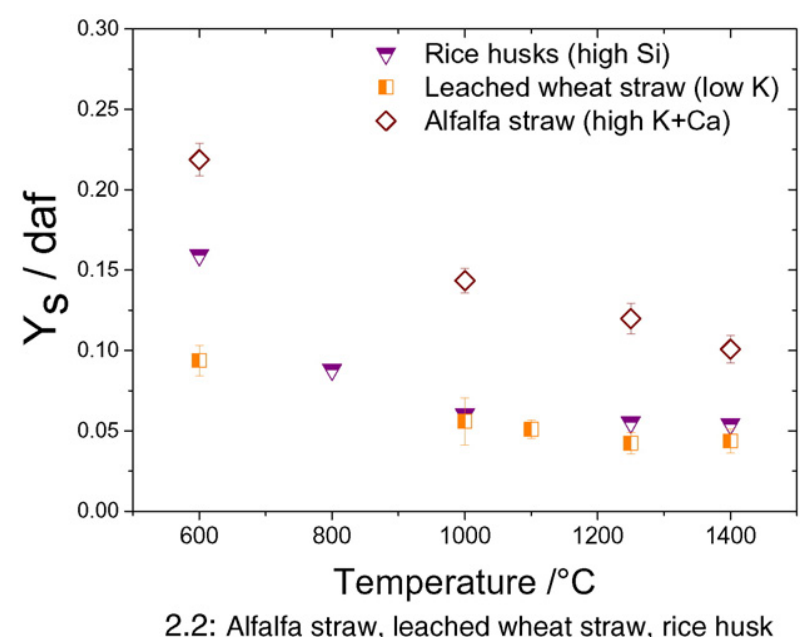

Fig. 2. Influence of heat treatment temperature on the char yield of biomasses, reacted in a $\mathrm{N}_{2}$ stream in WMR (heating rate: $1000{ }^{\circ} \mathrm{C} / \mathrm{s}$, holding time: $1 \mathrm{~s}$ ).

husk sample does not seem to affect the char yield, based on the similar char yields of rice husk (rich in $\mathrm{Si}$ ) and leached wheat straw (low presence of $\mathrm{Si}$ ).

In Fig. 3, the char yields of all biomasses used in this study are shown as a function of potassium content at heat treatment temperatures of

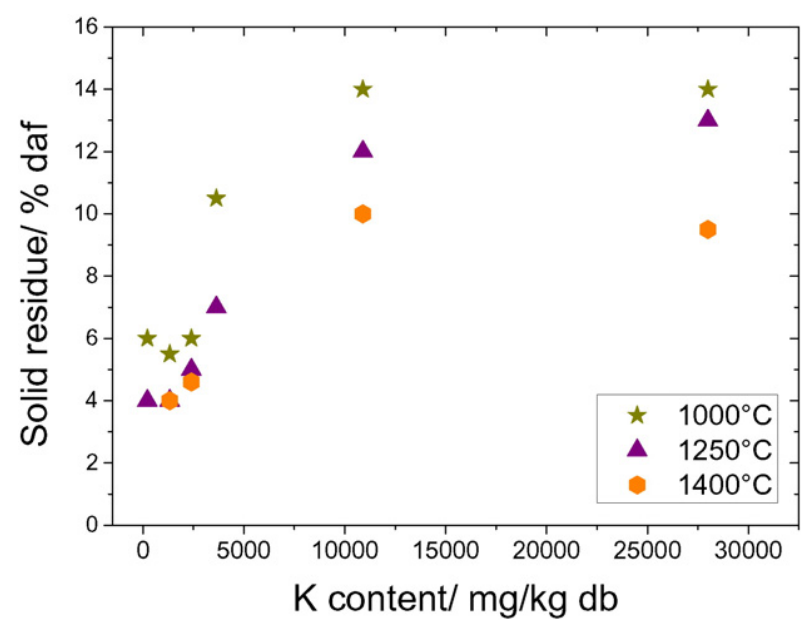

Fig. 3. Char yield versus only K element (heat treatment temperature: $1000{ }^{\circ} \mathrm{C}, 1250{ }^{\circ} \mathrm{C}$ and $1400{ }^{\circ} \mathrm{C}$, heating rate: $1000{ }^{\circ} \mathrm{C}$, holding time: $1 \mathrm{~s}$ ). 
1000-1400 ${ }^{\circ} \mathrm{C}$. The addition of Ca and Si does not improve the quality of the correlation compared with potassium only as shown in the supplemental material. The results clearly indicate a stronger catalytic effect of potassium on the char yield than calcium under fast heating, similarly to the findings of Nik-Azar et al. [34] and De Groot and Shafizadeh at low heating rates [36]. Their investigations showed that the high levels of potassium in the biomass increase the char yield at low and intermediate heating rate.

\subsubsection{Effect of heating rate}

A wire mesh reactor can be operated over a wide ranges of heating rates and holding times. This work is carried out using a heat treatment temperature of $1000{ }^{\circ} \mathrm{C}$ with a holding time of $1 \mathrm{~s}$ and heating rates from 10 to $3000{ }^{\circ} \mathrm{C} / \mathrm{s}$. Pinewood, beechwood and wheat straw were sieved to obtain the particle size fraction $0.05-0.2 \mathrm{~mm}$. In Fig. 4 , the influence of heating rate is represented for pinewood, beechwood and wheat straw. In general, higher heating rates give greater weight losses for all three fuels. The most significant effect of heating rate is observed in the region between 10 and $600{ }^{\circ} \mathrm{C} / \mathrm{s}$.

The tendency of a reduced influence of heating rate on the char yield above $>600{ }^{\circ} \mathrm{C} / \mathrm{s}$ seems to be consistent for all applied fuels, although a smaller further drop in char yield is seen at a high heating rate of $3000{ }^{\circ} \mathrm{C} / \mathrm{s}$. Zaror et al. [37] related the increased char yield at low heating rates to the longer residence times of volatiles in the particle, leading to predominance of secondary reactions with char, with tar cracking to form lighter compounds and char. Contrary to this, during fast heating a low molecular weight metaplast is formed due to the fast bond breaking, leading to an increased pressure inside the particle, fast volatiles evaporation, and a low char yield [21].

\subsubsection{Effect of holding time}

The effect of holding time in the WMR is studied for pinewood, wheat straw and leached wheat straw at 600 and $1000{ }^{\circ} \mathrm{C}$ with a heating rate of $1000{ }^{\circ} \mathrm{C} / \mathrm{s}$ and particle size fractions of $0.05-0.2$, $0.25-0.355,0.355-0.425,0.425-0.6,0.6-0.85$, and $0.85-1 \mathrm{~mm}$ as shown in Fig. 5 . At $600{ }^{\circ} \mathrm{C}$, particles of all biomasses with a mean diameter $<0.425 \mathrm{~mm}$ can be fully pyrolyzed within $2 \mathrm{~s}$. The larger pinewood particles require a longer holding time. The char yield of smaller particles with $2 \mathrm{~s}$ holding time seems to become slightly lower than the char yield of larger particles with $4 \mathrm{~s}$ holding time. The particle fraction from 0.6 to $0.85 \mathrm{~mm}$ at $600{ }^{\circ} \mathrm{C}$ exhibits a higher char yield than particles $<0.6 \mathrm{~mm}$. The differences between pinewood particle size fractions $0.05-0.6 \mathrm{~mm}$ and $0.6-1 \mathrm{~mm}$ indicate the significance of extra- and/or intra-particle thermal resistances for larger particles.

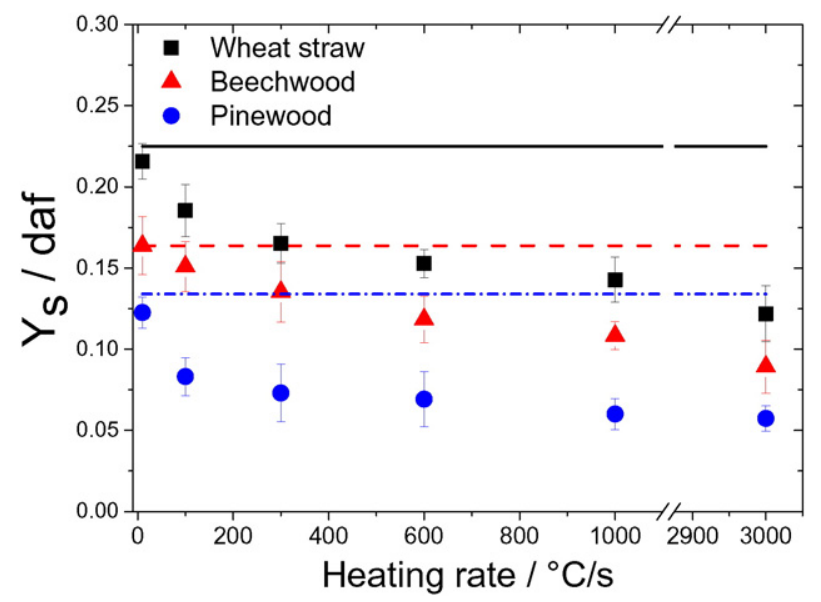

Fig. 4. Influence of heating rate on the char yield of wheat straw, beechwood and pinewood, pyrolyzed in WMR (heat treatment temperature: $1000{ }^{\circ} \mathrm{C}$, holding time: $1 \mathrm{~s}$ ) and shown as dots, and compared with the standard volatiles analysis at $900{ }^{\circ} \mathrm{C}$ and shown as lines.
Smaller particles are converted faster due to the larger heat fluxes, and because their temperature is more uniform (thermally thin), while the large particles have internal temperature gradients and thus a lower heat flux $\left(\mathrm{W} / \mathrm{m}^{2}\right)$, leading to a slower pyrolysis. It was found for fast heating rates relevant for pulverized fuel combustion [38-41] that the assumption of thermally thin particles is no longer valid when the biomass particle size exceeds $0.2 \mathrm{~mm}$. The pinewood particles between 0.05 and $0.85 \mathrm{~mm}$ are completely reacted within the first second of pyrolysis at $1000{ }^{\circ} \mathrm{C}$. For a complete pyrolysis of particles > $0.85 \mathrm{~mm}, 2 \mathrm{~s}$ holding time is required. Under the applied high heating rate $\left(1000{ }^{\circ} \mathrm{C} / \mathrm{s}\right)$, the particles with a mean diameter $<0.425 \mathrm{~mm}$ may be considered as thermally thin, while the inter-particle heat conduction in larger particles plays an important role in the biomass char conversion (pyrolysis and char burnout), and must be accounted for in mathematical models at temperatures $<1000{ }^{\circ} \mathrm{C}$ and at high heating rates. This observation is based on the almost negligible differences between char yields of particle size fractions in a range of $0.05 \mathrm{~mm}^{2} \mathrm{~d}_{p}<0.425 \mathrm{~mm}$.

The wheat straw at $600{ }^{\circ} \mathrm{C}$ and $1000{ }^{\circ} \mathrm{C}$ and leached wheat straw at $600{ }^{\circ} \mathrm{C}$ require $2 \mathrm{~s}$ for complete conversion. The demineralization of wheat straw decreases the required holding time for complete pyrolysis from 2 to $1 \mathrm{~s}$ at $1000{ }^{\circ} \mathrm{C}$. The leached wheat straw of size $>0.425 \mathrm{~mm}$ obtained a higher char yield at $600{ }^{\circ} \mathrm{C}$ than untreated straw within $1 \mathrm{~s}$. The present results show that at lower temperatures a high alkali content induces lower char yield, similarly to results of Saleh et al. [2]. Moreover, the holding time effect on the weight loss is not particularly dependent on the straw particle size. The pinewood particles tend to be more rod-like whereas wheat straw are more flake-like, based on the microscopic analysis, shown in supplemental material.

The flattened straw particles were probably kept aligned in the mesh pocket without any significant changes in the characteristic length over a wide range of apparent particle sizes. Thereby the required holding time for the complete pyrolysis at $600{ }^{\circ} \mathrm{C}$ was shorter in comparison to the non-flattened pinewood particles, where the width may turn out to be a characteristic length. The characteristic length plays a predominant role in the fuel conversion at temperatures $\leq 1000{ }^{\circ} \mathrm{C}$ with the non-sufficient holding time, so that more flattened particles yield less char. Particles of larger thicknesses cause higher internal mass and heat transfer resistance resulting in thinner relative thickness of the char conversion region during pyrolysis. The present results show that the effect of holding time depends strongly on the heat treatment temperature.

\subsubsection{Effect of particle size}

The effect of particle size $(0.05-0.2,0.25-0.355,0.355-0.425$, $0.425-0.6,0.6-0.85,0.85-1 \mathrm{~mm}$ ) was studied using pinewood, wheat straw and leached wheat straw. The experiments were carried out at $1000{ }^{\circ} \mathrm{C}$ and $1250{ }^{\circ} \mathrm{C}$ with a heating rate of $1000{ }^{\circ} \mathrm{C} / \mathrm{s}$ and $2 \mathrm{~s}$ holding time. The experimental results obtained at $600{ }^{\circ} \mathrm{C}$ clearly indicate that a holding time of $1 \mathrm{~s}$ was not enough to convert particles above $0.355 \mathrm{~mm}$, and the results are shown in the supplementary material.

The char yields are illustrated in Fig. 6. By raising the temperature from $1000{ }^{\circ} \mathrm{C}$ up to $1250{ }^{\circ} \mathrm{C}$, the char yield decreases for all particle sizes. The experimental data in this work show a slight char yield growth when a particle size is increased from $0.6 \mathrm{~mm}$ to $0.1 \mathrm{~mm}$ at $1000{ }^{\circ} \mathrm{C}$ and $1250{ }^{\circ} \mathrm{C}$, indicating a slower pyrolysis for the large particles which leads to an increased char yield. Yet, it seems that the particles size change from $0.05 \mathrm{~mm}$ to $1 \mathrm{~mm}$ of all biomasses with the $2 \mathrm{~s}$ holding time has less influence on the char yield than the heat treatment temperature.

For comparison, Fig. 6 also shows char yields for pine wood obtained for large 3, 4 and $5 \mathrm{~mm}$ cubes in a single particle reactor at temperatures of $1190{ }^{\circ} \mathrm{C}, 1350{ }^{\circ} \mathrm{C}$ and $1450{ }^{\circ} \mathrm{C}$ [42]. The single particle reactor was designed for oxidation and pyrolysis studies on fuel particles $>2 \mathrm{~mm}$ at temperatures up to $1500{ }^{\circ} \mathrm{C}$ and high heating rates [43]. The char yield, based on averaging 15 experiments, is plotted as a function of 


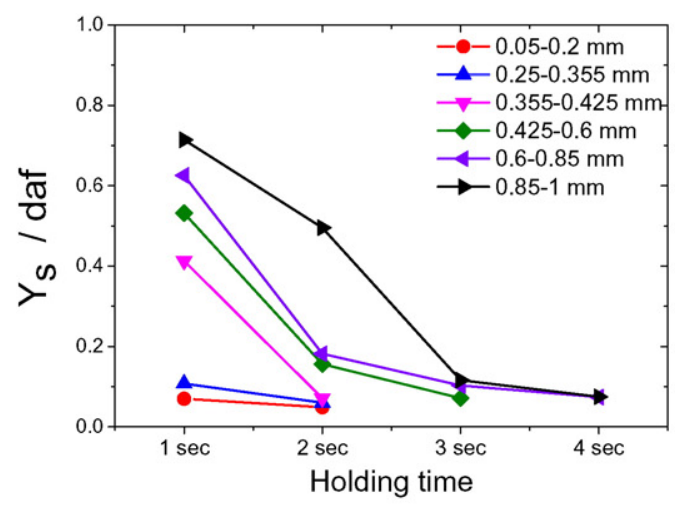

5.1: Pinewood, $600^{\circ} \mathrm{C}$

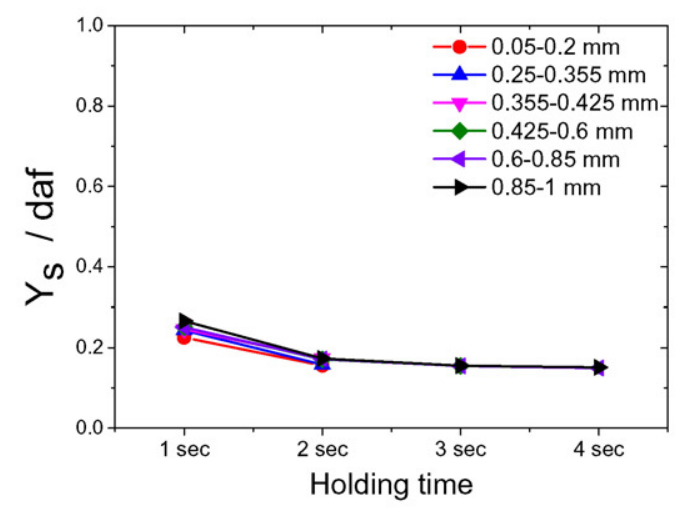

5.3: Wheat straw, $600^{\circ} \mathrm{C}$

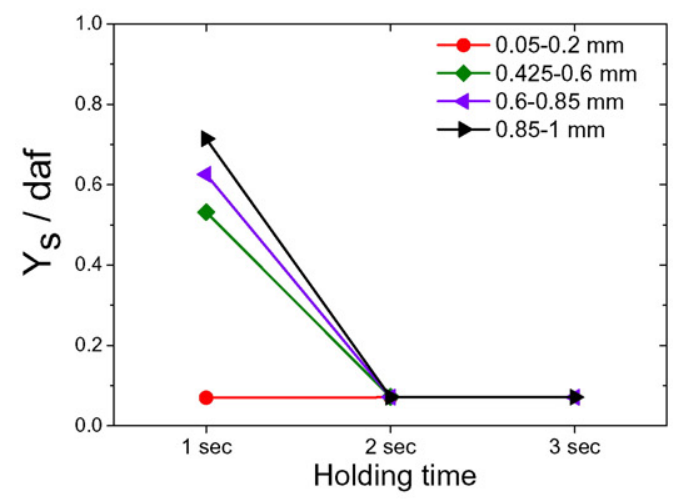

5.5: Leached wheat straw, $600^{\circ} \mathrm{C}$

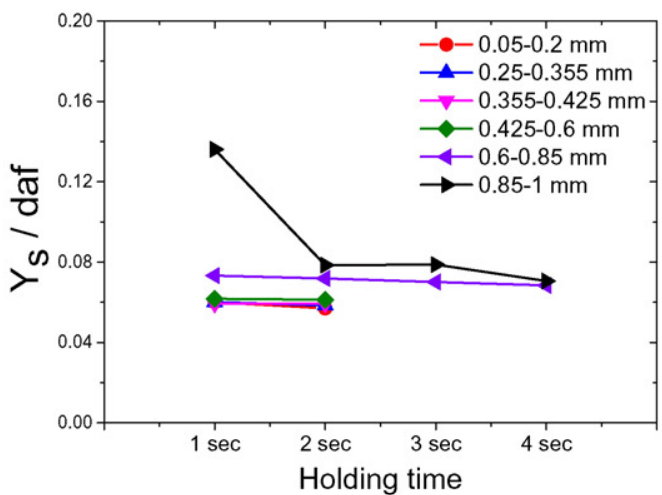

5.2: Pinewood, $1000^{\circ} \mathrm{C}$

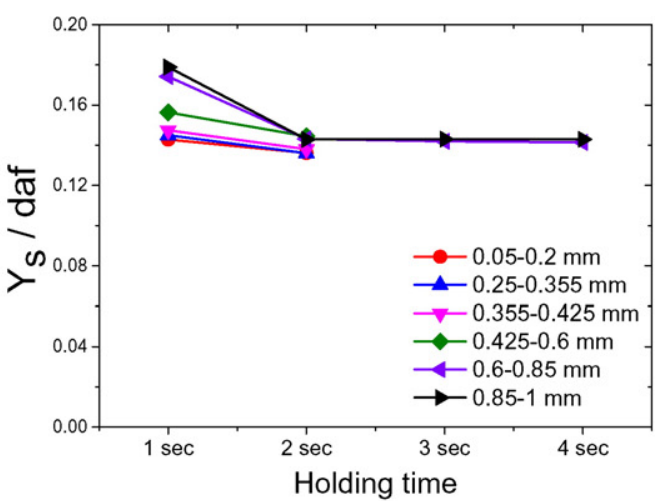

5.4: Wheat straw, $1000^{\circ} \mathrm{C}$

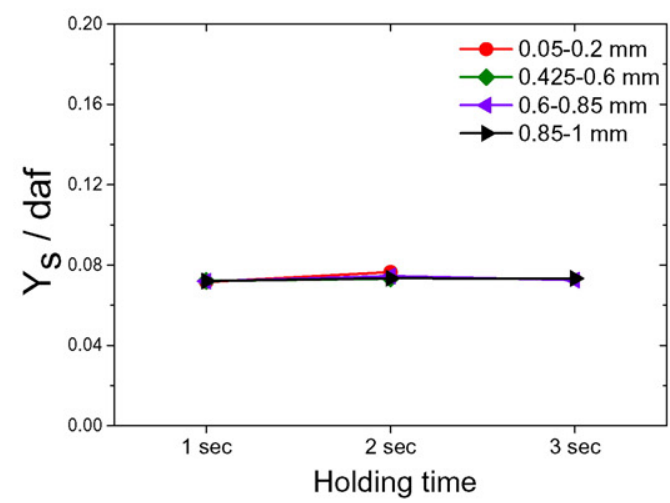

5.6: Leached wheat straw, $1000^{\circ} \mathrm{C}$

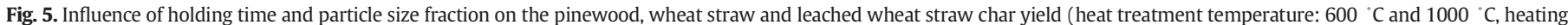
rate: $1000{ }^{\circ} \mathrm{C} / \mathrm{s}$ ).

heat treatment temperature and particle size. The char yield of the $3 \mathrm{~mm}$ pinewood cube decreases from ca. 7.3 to $6.0 \%$ when the temperature is raised from $1190{ }^{\circ} \mathrm{C}$ to $1450{ }^{\circ} \mathrm{C}$. A similar tendency in terms of a decreasing char yield with higher temperatures is observed for the 4 and $5 \mathrm{~mm}$ pinewood particles. Moreover, the differences between the char yields at different temperatures become less pronounced with increasing particle size. The results of $5 \mathrm{~mm}$ cube pyrolysis indicate no differences in a weight loss at $1190{ }^{\circ} \mathrm{C}$ and $1350{ }^{\circ} \mathrm{C}$, while at $1450{ }^{\circ} \mathrm{C}$ the char yield decreases from 8.5 to $7.7 \%$. The char yield of the $5 \mathrm{~mm}$ pinewood particle is higher than for the $3 \mathrm{~mm}$ and $4 \mathrm{~mm}$ particles.

In Fig. 6, the results of pinewood pyrolysis are compared with the results for wheat straw and leached wheat straw in order to understand the effect of biomass particle size in dependency on the biomass origin. The wheat straw and leached wheat straw show also a slightly increased char yield as the particle sizes increase from $0.05 \mathrm{~mm}$ to
$1 \mathrm{~mm}$ at $1000{ }^{\circ} \mathrm{C}$ and $1250{ }^{\circ} \mathrm{C}$. The char yield of pinewood at $1000{ }^{\circ} \mathrm{C}$ and $1250{ }^{\circ} \mathrm{C}$ corresponds to the leached wheat straw results, except for the $0.85-1 \mathrm{~mm}$ particle size result.

\subsection{Char morphology and structural transformations}

The char morphology and structural transformations from the fast pyrolysis of pinewood, wheat straw, alfalfa straw and rice husk in the wire mesh reactor at a temperature range of $350-1400{ }^{\circ} \mathrm{C}$ were compared with data from a heat treatment temperature at $1000{ }^{\circ} \mathrm{C}$ and a heating rate of $10{ }^{\circ} \mathrm{C} / \mathrm{min}$ in a tubular furnace. This comparison shows the effect of heating rate and temperature on the char structural transformations during pyrolysis.

The current investigation shows softening of the solid char matrix already at $350{ }^{\circ} \mathrm{C}$ at both low and high heating rates as it can be observed 


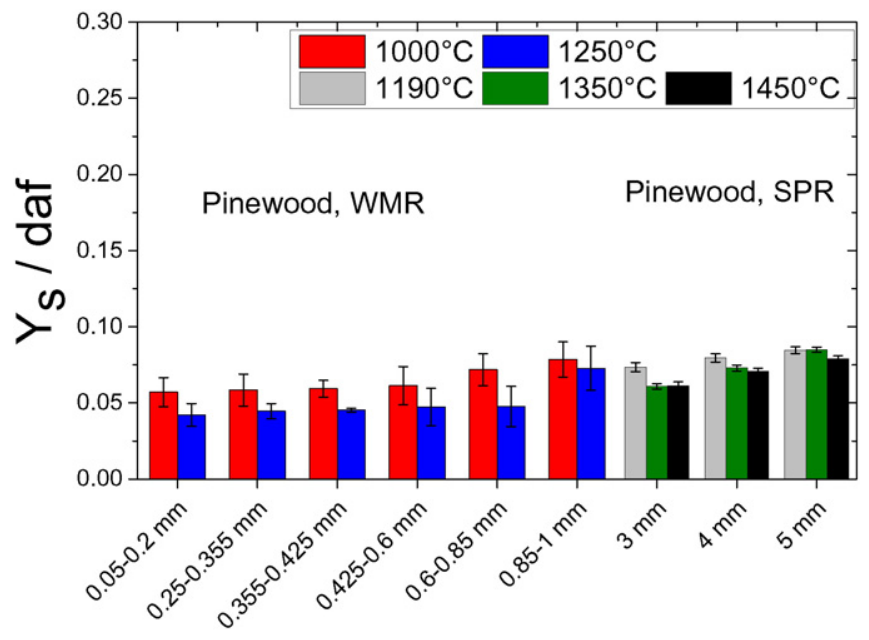

6.1: Pinewood in WMR and SPR

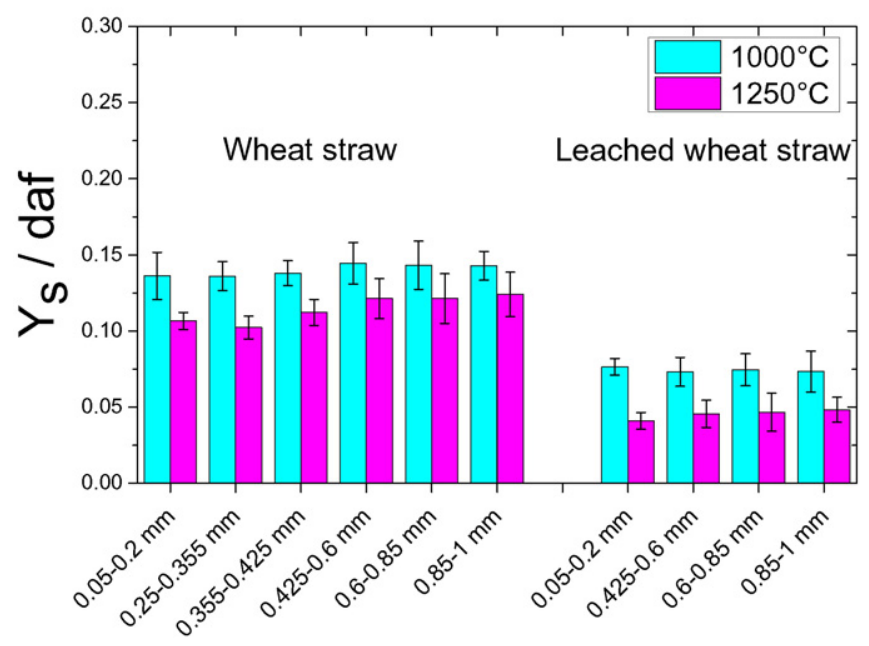

\section{2: Wheat straw and leached wheat straw}

Fig. 6. Influence of particle size on the char yield of pinewood, wheat straw and leached wheat straw, pyrolyzed in WMR (heat treatment temperature: $1000{ }^{\circ} \mathrm{C}$ and $1250{ }^{\circ} \mathrm{C}$, heating rate: $1000{ }^{\circ} \mathrm{C} / \mathrm{s}$, holding time: $2 \mathrm{~s}$, particle size: $0.05-1 \mathrm{~mm}$ ) and in SPR (heat treatment temperature: $1190{ }^{\circ} \mathrm{C}, 1350{ }^{\circ} \mathrm{C}, 1450{ }^{\circ} \mathrm{C}$, particle size: $3-5 \mathrm{~mm}$ ).

from SEM images in supplemental material. In contrast to results of Cetin et al. [3] who reported negligible morphological changes at low heating rates, the data in this study indicate softening of pinewood and wheat straw solid matter at $1000{ }^{\circ} \mathrm{C}$ with a heating rate of $10{ }^{\circ} \mathrm{C} / \mathrm{min}$ as shown in Fig. 7. However, the plasticization at high heating rates is stronger than at low heating rates, as can be seen by the microscopy observations in this study.

The devolatilization and fluidity of biomass involve the same basic steps as in the devolatilization of coal, i.e. bond breaking, possible formation of a metaplast, evaporation of tar and release of light gases, followed by repolymerization finally forming a char. In low rank coals such as lignite, which have a high oxygen content, low temperature bond formation (mainly ethers) can take place as well, which to some extent may prevent formation of a metaplast $[20,21,44,45]$. The situation for biomass is complicated by the fact that it contains three distinctly different building blocks, i.e. cellulose, hemicellulose and lignin. The cellulose and hemicellulose are quite different from coal structures while the lignin has more resemblance with coal, containing aromatic moieties [45,46]. However, both pure cellulose [47], with its relatively weak hemi-acetal bonds, and lignin $[35,44]$ are known to form a melt at high heating rates and there is no reason to believe that hemicelluloses will not do the same under similar conditions. De Groot and
Shafizadeh [36] suggested that the decomposition of hemicelluloses contributes significantly to char formation and morphology due to the close association of inorganic species with the hemicelluloses through ion exchange on glucuronic acid groups.

Moreover, the inorganic matter, that resides as minerals in coal, influences the pyrolysis behavior in a different way than in the case of biomass, where potassium and calcium play a role as active catalysts that may additionally affect the metaplast formation [35]. Yet, it is not well known to what extent the formation of a metaplast depends on the presence of alkali, and how this influence is changed with heating rate.

Heating rates affect the melting and swelling behavior of both biomass and coal and thereby how the competing processes of tar formation (bond-breaking, cross-linking, internal mass transport) change with the temperature. The heating rates determine the temperature at which the reaction occur [48]. Under slower heating conditions, plasticization on the char surface is hindered by cross-linking prior to bridge-breaking. At high heating rates, biomass behaves similarly to the bituminous coals and undergoes significant bridge-breaking before it starts to cross-link and therefore becomes fluid.

Cetin et al. $[3,49]$ assigned the melting of fuel at high heating rates to a lack of cell structure, causing plastic transformation on the char surface. The results of this work as shown in Fig. 7 show that the differences in morphological transformations at $600{ }^{\circ} \mathrm{C}$ and $1000{ }^{\circ} \mathrm{C}$ are not significant for pinewood and wheat straw in terms of plasticization, probably because the primary pyrolysis reactions occur at temperatures $<600{ }^{\circ} \mathrm{C}$.

Moreover, alfalfa straw and rice husk underwent plastic deformation during fast pyrolysis in the wire mesh reactor, but with less melting than the pinewood, indicating an effect of ash on the char morphology as shown in Fig. 8. The alfalfa straw char at $1250{ }^{\circ} \mathrm{C}$ shows an increase in macropores. It loses its structural distinctions and maintains a very fragile and thin walled layer consisting of several molten fused particles. The high levels of $\mathrm{K}$ and $\mathrm{Ca}$ in the alfalfa straw may cause less severe plasticization, similarly to the wheat straw, by catalyzing the conversion of bridges into char links, and therefore increasing polymerization/ cross-linking and reducing char fluidity.

The preserved rice husk char shape is probably mainly related to the high content of Si that hinders char polymerization/cross-linking. At high temperatures, a stable shell of rice husk char is formed, probably due to the softening of amorphous $\mathrm{SiO}_{2}$ at about $700{ }^{\circ} \mathrm{C}$, and when it is rapidly cooled, the silicon melt solidifies without crystallization [50]. The formation of glassy structures in the rice husk may be caused by the presence of potassium that could decrease the melting temperature of $\mathrm{SiO}_{2}$ [51], leading to a stronger char transformation at $1400{ }^{\circ} \mathrm{C}$ in comparison to chars, prepared at $1000{ }^{\circ} \mathrm{C}$ and $1250{ }^{\circ} \mathrm{C}$ as shown in the supplemental material.

The morphological changes of biomass during pyrolysis may be a result of the degradation of different plant components that affect the metaplast formation. Hemicellulose degradation is known to occur over a relatively broad range of temperatures, and it forms more char than cellulose [52]. The results of this study on the hemicellulose correspond to the investigations of Sharma et al. [53] at $350{ }^{\circ} \mathrm{C}$ under slow heating, where molten clusters of a pectin char were formed with the closed vesicles and open pores.

The cellulose char, prepared at a peak temperature of $1000{ }^{\circ} \mathrm{C}$, was available on the mesh only in a very small quantity. Fig. 8 suggests that the hemicellulose char solidifies after the fast pyrolysis, and forms a glassy amorphous structure, similarly to the cellulose, which was probably even stronger plasticized. Lignin tends to be less volatile than cellulose and hemicellulose, leading to the formation of higher char yields [54].

Fig. 8 also shows the foamed softwood and hardwood lignin types at $1000{ }^{\circ} \mathrm{C}$ with the formation of elongated vesicles on a smooth surface. The current investigation indicates an intensive swelling and foaming of lignin at $350{ }^{\circ} \mathrm{C}$ as it is shown in supplemental material. The optical differences between softwood and wheat straw are nearly negligible. In this study it is believed that under fast heating the formation of 


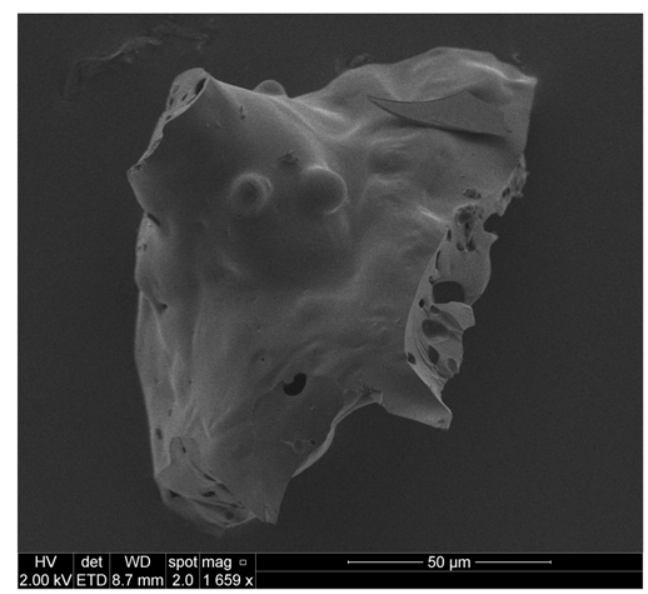

7.1: Pinewood, $1000^{\circ} \mathrm{C} / \mathrm{s}$

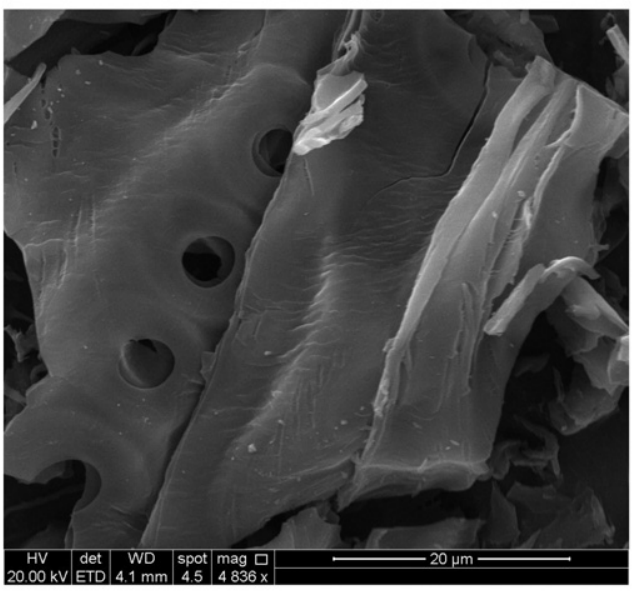

7.3: Pinewood, $10^{\circ} \mathrm{C} / \mathrm{min}$

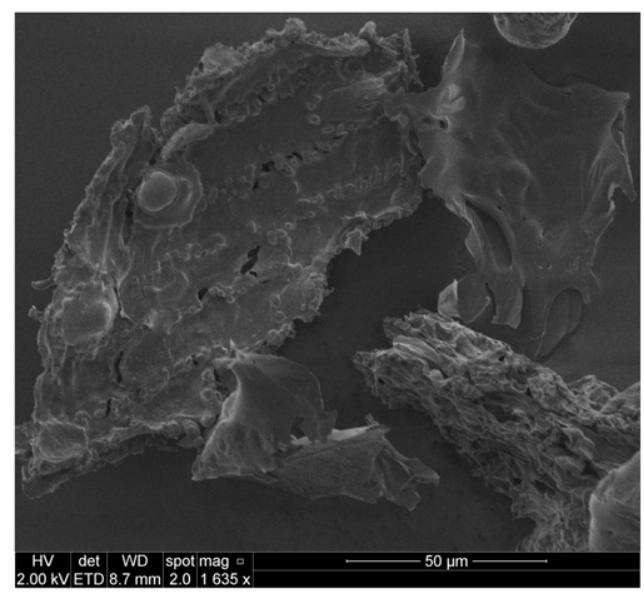

7.2: Wheat straw, $1000^{\circ} \mathrm{C} / \mathrm{s}$

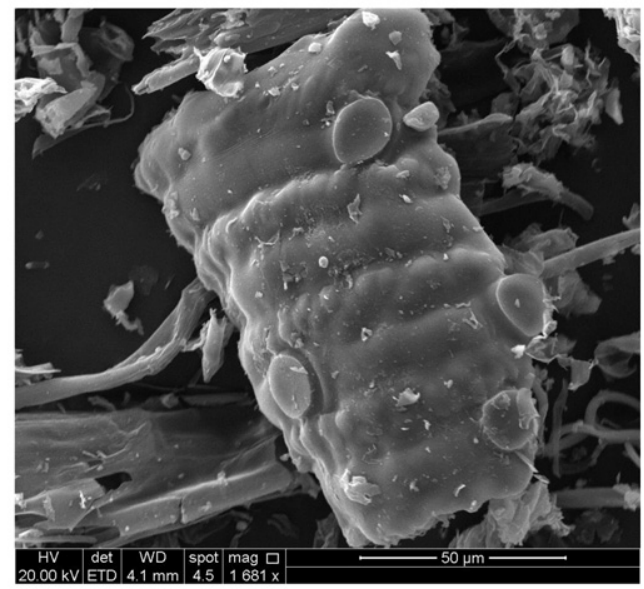

7.4: Wheat straw, $10^{\circ} \mathrm{C} / \mathrm{min}$

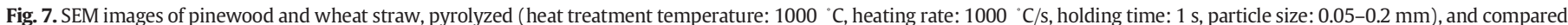
with particles (heat treatment temperature: $1000{ }^{\circ} \mathrm{C}$, heating rate: $10{ }^{\circ} \mathrm{C} / \mathrm{min}$, holding time: $10 \mathrm{~min}$, particle size: $0.05-0.2 \mathrm{~mm}$ ).

metaplast is mostly affected by the bond-breaking and cross-linking of organic components present in lignin that is less volatile than holocelluses. The stronger plasticized chars of pinewood and beechwood contain higher fractions of lignin (>30\%) than herbaceous chars with (20-26\%). The high presence of inorganic matter in herbaceous biomass may also affect the metaplast formation, resulting in a less plasticized char.

Interestingly, Jepsen [42] also reported in his pyrolysis experiments with larger pinewood particles that the surfaces of $3 \mathrm{~mm}$ and $5 \mathrm{~mm}$ particles were plasticized with the formation of elongated pores in the cutting direction of the original pinewood during pyrolysis. This indicates that even for large particles fast heating rates at the surface may lead to local formation of a metaplast. Metaplast formation was not observed inside the particles, presumably due to lower heating rates.

\section{Conclusions}

The aim of the current investigation was to understand the effect of heat treatment temperature, heating rate, particle size, holding time and fuel origin on the char yield and morphology for chars prepared under fast heating. The experimental study was performed in a wire mesh reactor. The structural transformations of chars were characterized with SEM microscopy to understand mostly the effect of fast heating rate $\left(1000{ }^{\circ} \mathrm{C} / \mathrm{s}\right)$ and biomass origin with respect to the ash components (K, Ca and $\mathrm{Si}$ ) and organic matter (cellulose, hemicellulose, lignin) on the char formation.

The largest effect of heating rate on the char yield was observed in the region between $10{ }^{\circ} \mathrm{C} / \mathrm{s}$ and $600{ }^{\circ} \mathrm{C} / \mathrm{s}$. Above $>600{ }^{\circ} \mathrm{C} / \mathrm{s}$ the char yield seemed to become relatively insensitive to the heating rate increase. The heat treatment temperature and presence of potassium and possibly to a small extent by calcium affected the char yield stronger than the heating rates and differences in the plant component levels. At the applied heating rates, up to $3000{ }^{\circ} \mathrm{C} / \mathrm{s}$, the particle could be assumed to be thermally thin, when its size did not exceed $0.425 \mathrm{~mm}$. The char yields of wheat straw and leached wheat straw were less affected by the holding time and particle size because the characteristic length for heat transport was determined by the particle thickness.

Scanning electron microscopy on the chars indicated structural transformations of all biomasses during both fast and slow pyrolysis. At high heating rates, the char underwent strong deformation with clear signs of melting and development of macropores at all applied temperatures. The ability of char to melt under the fast heating followed the order softwood $>$ hardwood $>$ wheat straw, alfalfa straw $>$ rice husk, and was related to the formation of metaplast where lignin contributes probably more than holocelluloses due to its lower volatility. In addition, an essential catalytic effect of $\mathrm{K}$ and to a minor extent $\mathrm{Ca}$ on the fuel structural changes was hypothesized, probably owing to a stronger cross-linking of herbaceous chars, leading to the less fluidity. The 


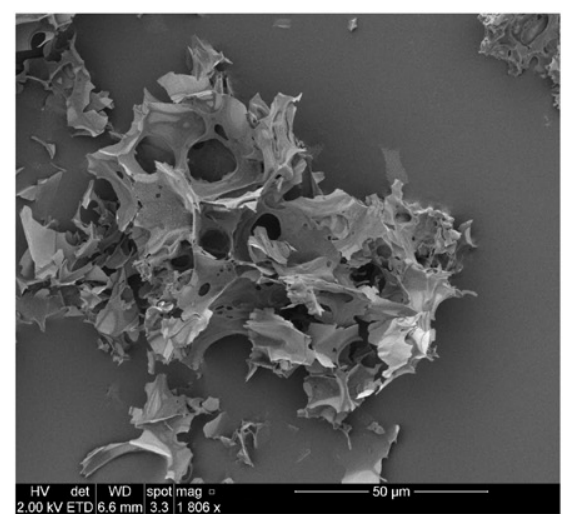

8.1: Alfalfa straw char

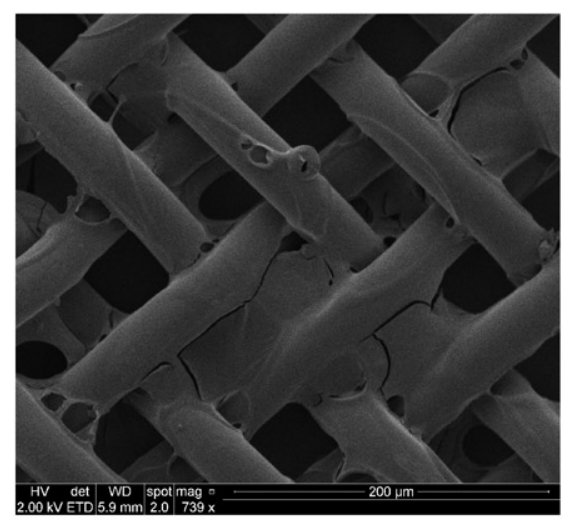

8.3: Cellulose char

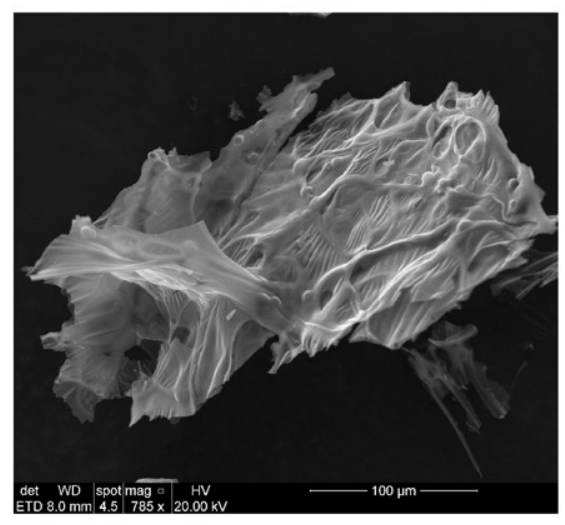

8.5: Lignin (softwood) char

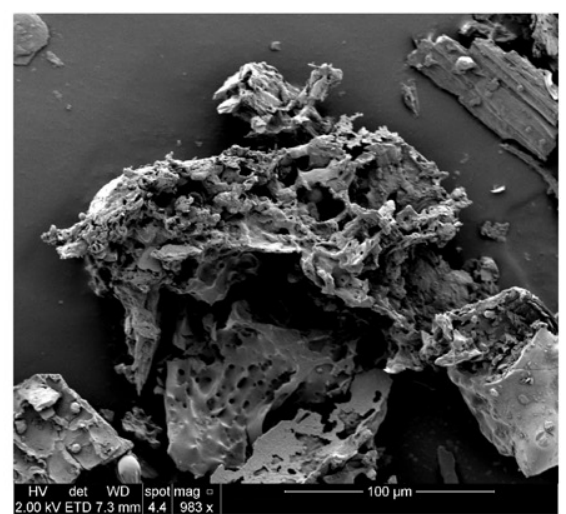

8.2: Rice husk char

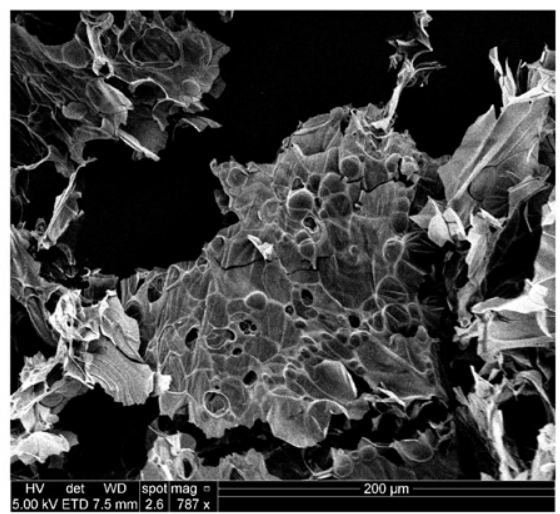

8.4: Xylan char

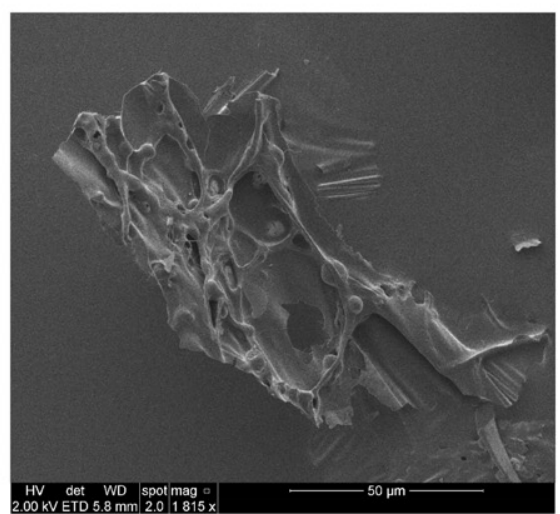

8.6: Lignin (straw) char

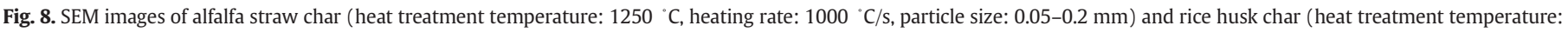

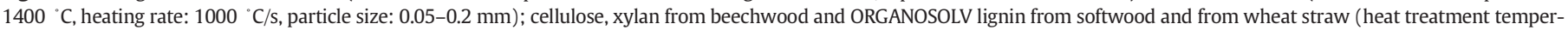
ature: $1000{ }^{\circ} \mathrm{C}$, heating rate: $1000{ }^{\circ} \mathrm{C} / \mathrm{s}$, particle size: $0.05-0.1 \mathrm{~mm}$ ), pyrolyzed in WMR.

smaller structural changes of rice husk chars were attributed to their high content of silicon.

\section{Acknowledgements}

The authors would like to acknowledge the financial support that they received for this project from Danish Strategic Research Council, DONG Energy and Vattenfall. We also thank DTU Danish Polymer Center, DTU CEN, and Jesper Harholt (University of Copenhagen) for assisting with hemicellulose purification, microscopy measurements, and biomass compositional analysis.

\section{Appendix A. Supplementary data}

Supplementary data to this article can be found online at http://dx. doi.org/10.1016/j.fuproc.2015.08.034.

\section{References}

[1] K. Lu, E. Ip, J. Scott, P. Foster, M. Vickers, L.L. Baxter, Effects of particle shape and size on devolatilization of biomass particle, Fuel 89 (2010) 1156-1168.

[2] S.B. Saleh, B.B. Hansen, P.A. Jensen, K. Dam-Johansen, Influence of biomass chemical properties on torrefication characteristics, Energy Fuel 27 (2013) 7541-7548.

[3] E. Cetin, B. Moghtaderi, R. Gupta, T.F. Wall, Influence of pyrolysis conditions on the structure and gasification reactivity of biomass chars, Fuel 83 (2004) 2139-2150. 
[4] P. Holmgren, K. Umeki, A. Strandberg, D.R. Wagner, R. Molinder, H. Wiinikka, et al., Size, shape and density changes of biomass particles during devolatilization in a drop tube furnace, Proc 22nd European Biomass Conference and Exhibition, June 23rd-26th 2014 (Hamburg, Germany).

[5] R. Zanzi, K. Sjöström, E. Björnbom, Rapid high-temperature pyrolysis in a free-fall reactor, Fuel 75 (1996) 545-550.

[6] A.R. Fraga, A.F. Gaines, R. Kandiyoti, Characterization of biomass pyrolysis tars produced in the relative absence of extraparticle secondary reactions, Fuel 70 (1991) 895-903.

[7] M.R. Hajaligol, J.B. Howard, W. Peters, An experimental and modeling study of pressure effects on tar release by rapid pyrolysis of cellulose sheets in a screen heater, Combust. Flame 95 (1993) 47-60.

[8] R. Zanzi, K. Sjöström, E. Björnbom, Rapid pyrolysis of agricultural residues at high temperature, Biomass Bioenergy 23 (2002) 357-366.

[9] J. Svenson, J.B.C. Pettersson, K.O. Davidsson, Fast pyrolysis of the main components of Birchwood, Combust. Sci. Technol. 176 (2004) 977-990.

[10] J. Guo, Pyrolysis of wood powder and gasification of wood-derived char( $\mathrm{PhD}$ thesis) Eindhoven University of Technology, 2004.

[11] Y. Zhang, S. Kajitani, M. Ashizawa, K. Miura, Peculiarities of rapid pyrolysis of biomass covering medium- and high-temperature ranges, Energy Fuel 20 (2006) 2705-2712.

[12] H. Lu, Experimental and modeling investigations of biomass particle combustion (PhD thesis) Brigham Young University, 2006.

[13] M. Dall'Ora, P.A. Jensen, A.D. Jensen, Suspension combustion of wood: influence of pyrolysis conditions on char yield, morphology, and reactivity, Energy Fuel 22 (2008) 2955-2962.

[14] G. Di Nola, W. De Jong, H. Spliethoff, The fate of main gaseous and nitrogen species during fast heating rate devolatilization of coal and secondary fuels using a heated wire mesh reactor, Fuel Process. Technol. 90 (2009) 388-395.

[15] Y. Zhang, S. Kajitani, M. Ashizawa, Y. Oki, Tar destruction and coke formation during rapid pyrolysis and gasification of biomass in a drop-tube furnace, Fuel 89 (2010) 302-309.

[16] S. Sun, H. Tian, Y. Zhao, R. Sun, H. Zhou, Experimental and numerical study of biomass flash pyrolysis in an entrained flow reactor, Bioresour. Technol. 101 (2010) 3678-3684.

[17] A.V. Sepman, L.P.H. de Goey, Plate reactor as an analysis tool for rapid pyrolysis of biomass, Biomass Bioenergy 35 (2011) 2903-2909.

[18] K. Umeki, K. Kirtania, L. Chen, S. Bhattacharya, Fuel particle conversion of pulverized biomass during pyrolysis in an entrained flow reactor, Ind. Eng. Chem. Res. 51 (2012) 13973-13979.

[19] S. Septien, S. Valin, C. Dupont, M. Peyrot, S. Salvador, Effect of particle size and temperature on woody biomass fast pyrolysis at high temperature $\left(1000-1400{ }^{\circ} \mathrm{C}\right)$, Fuel 97 (2012) 202-210.

[20] M.A. Serio, S. Charpenay, R. Bassilakis, P.R. Solomon, Measurement and modeling of lignin pyrolysis, Biomass Bioenergy 7 (1994) 107-124.

[21] P.R. Solomon, M.A. Serio, E.M. Suuberg, Coal pyrolysis: experiments, kinetic rates and mechanisms, Prog. Energy Combust. Sci. 18 (1992) 133-220.

[22] A. Sluiter, B. Hames, R. Ruiz, C. Scarlata, J. Sluiter, D. Templeton, et al., Determination of structural carbohydrates and lignin in biomass, National Renewable Energy Laboratory, Golden (CO), July 2011 (Report No. NREL/TP-510-42618. Contract No.: DEAC36-08-G028308)

[23] S. Willför, J. Hemming, A.S. Leppänen, Analysis of extractives in different pulps method development, evaluation, and recommendations, Report No. B1 of the EU COST E41 Action "Analytical Tools with Applications for Wood and Pulping Chemistry", Åbo Akademi University, Laboratory of Wood and Paper Chemistry, Finland, 2004-2009.

[24] B. Hames, R. Ruiz, C. Scarlata, J. Sluiter, A. Sluiter, Preparation of Samples for Compositional Analysis, National Renewable Energy Laboratory, Golden (CO), June 2011 (Report No. NREL/TP-510-42620. Contract No.: DE-AC36-99-G010337).

[25] Y. Chen, N.M. Stark, M.A. Tschabalala, J. Gao, Y. Fan, Moisture performance of woodplastic composites reinforced with extracted and delignified wood flour, Proc ANTEC, April $28^{\text {th }}-30^{\text {th }} 2014$.

[26] A.L. Horvath, Solubility of structurally complication materials: I. Wood, J. Phys. Chem. Ref. Data 35 (1) (2006) 77-92.
[27] A. Demirbas, Methylation of wood fatty and resin acids for production of biodiesel, Fuel 90 (2011) 2273-2279.

[28] K. Thammasouk, D. Tandjo, M.H. Penner, Influence of extractives on the analysis of herbaceous biomass, J. Agric. Food Chem. 45 (1997) 437-443.

[29] A. Tremel, H. Spliethoff, Gasification kinetics during entrained flow gasification part I; devolatilisation and char deactivation, Fuel 103 (2013) 663-671.

[30] E. Hoekstra, W.P.M. van Swaaij, S.R.A. Kersten, K.J.A. Hogendoorn, Fast pyrolysis in a novel wire mesh reactor: design and initial results, Chem. Eng. J. 191 (2012) 45-58

[31] A. Tremel, Reaction kinetics of solid fuels during entrained flow gasification (PhD thesis) TU Munich, 2012.

[32] J. Werkelin, M. Hupa, Release of ash-forming matter of woody biomass during fast pyrolysis in a wire mesh reactor, Proc Impacts Fuel Qual Power Prod Envir, Aug. 30th-Sep. 3rd 2010 (Saariselkä, Finland).

[33] A.D. Jensen, K. Dam-Johansen, M.A. Wojtowicz, M.A. Serio, TG-FTIR study of the influence of potassium chloride on wheat pyrolysis, Energy Fuel 12 (1998) 929-938.

[34] M. Nik-Azar, M.R. Hajaligol, M. Sohrabi, B. Dabir, Mineral matter effects in rapid pyrolysis of beechwood, Fuel Process. Technol. 51 (1997) 1539-1552.

[35] S. Niksa, Predicting the rapid devolatilization of diverse forms of biomass with bioflashschain, Proc. Combust. Inst. 28 (2000) 2727-2733.

[36] W.F. De Groot, F. Shafizadeh, The influence of exchangeable cations on the carbonization of biomass, J. Anal. Appl. Pyrolysis 6 (1984) 217-232.

[37] C.A. Zaror, I.S. Hutchings, D.L. Pyle, H.N. Stiles, R. Kandiyoti, Secondary char formation in the catalytic pyrolysis of biomass, Fuel 64 (1985) 990-994.

[38] L. Ma, J.M. Jones, M. Pourkashanian, A. Williams, Modelling the combustion of pulverized biomass in an industrial combustion test furnace, Fuel 86 (2007) 1959-1965.

[39] S. Jimenez, P. Remacha, J.C. Ballesteros, A. Gimenez, J. Ballester, Kinetics of devolatilization and oxidation of a pulverized biomass in an entrained flow reactor under realistic combustion conditions, Combust. Flame 152 (2008) 588-603.

[40] Y.B. Yang, V.N. Sharifi, J. Swithenbank, L. Ma, L.I. Darvell, J.M. Jones, M. Pourkashanian, A. Williams, Combustion of a single particle of biomass, Energy Fuel 22 (2008) 306-316.

[41] S.R. Gubba, M. Pourkashanian, A. Williams, Influence of particle shape and internal thermal gradients of biomass particles on pulverized coal/biomass co-fired flames, Fuel Process. Technol. 92 (2011) 2185-2195.

[42] M.S. Jepsen, Pyrolysis of large biomass particles in a single particle combustion reactor (M.Sc. thesis) DTU Chemical Engineering, Technical University of Denmark, 2014.

[43] M. Momeni, C. Yin, S.K. Koer, T.B. Hansen, P.A. Jensen, P. Glarborg, Experimental study on effects of particle shape and operating conditions on combustion characteristics of single biomass particles, Energy Fuel 27 (2013) 507-514.

[44] Y. Chen, S. Charpenay, A. Jensen, M.A. Serio, M.A. Wojtowicz, Modeling biomass pyrolysis kinetics and mechanisms, ACS Div. Fuel Chem. 213 (1997) 96-100.

[45] P.R. Solomon, D.G. Hamblen, M.A. Serio, Z.Z. Yu, A characterization method and model for predicting coal conversion behaviour, Fuel 72 (1993) 107-124.

[46] R. Bassilakis, R.M. Carangelo, M.A. Wojtowicz, TG-FTIR analysis of biomass pyrolysis, Fuel 80 (2001) 1765-1786.

[47] P.J. Dauenhauer, J.L. Colby, C.M. Balonek, W.J. Suszynski, L.D. Schmidt, Reactive boiling of cellulose for integrated catalysis through an intermediate liquid, Green Chem. 11 (2009) 1555-1561.

[48] P.R. Solomon, D.G. Hamblen, R.M. Carangelo, M.A. Serio, G.V. Deshpande, Genera model of coal devolatilization, Biomass Bioenergy 2 (1988) 405-422.

[49] E. Cetin, B. Moghtaderi, R. Gupta, T.F. Wall, Biomass gasification kinetics: influences of pressure and char structure, Combust. Sci. Technol. 177 (2005) 765-791.

[50] A. Hedler, S.L. Klaumünzer, W. Wesch, Amorphous silicon exhibits a glass transition, Nat. Mater. 3 (2004) 804-809.

[51] A. Bharadwaj, Y. Wang, S. Sridhar, V.S. Arunachalam, Pyrolysis of rice husk, Curr. Sci. 87 (2004) 981-986.

[52] R.K. Sharma, J.B. Wooten, V.L. Baliga, X. Lin, W.G. Chan, M.R. Hajaligol, Characterisation of chars from pyrolysis of lignin, Fuel 83 (2004) 1469-1482.

[53] R.K. Sharma, J.B. Wooten, V.L. Baliga, M.R. Hajaligol, Characterization of chars from biomass-derived materials: pectin chars, Fuel 80 (2001) 1825-1836.

[54] J.J.M. Orfao, F.J.A. Antunes, J.L. Figueiredo, Pyrolysis kinetics of lignocellulosic materials - three independent reactions model, Fuel 78 (1999) 349-358. 